\title{
Local Energy Planning Potentialities in Reducing São Paulo's Inequalities
}

\author{
Flávia Mendes de Almeida Collaço \\ Célio Bermann
}

${ }^{I}$ Instituto de Estudos Avançados (IEA-USP), São Paulo, SP, Brasil.

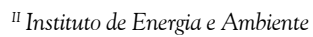
(IEE-USP), São Paulo, SP, Brasil.

\begin{abstract}
This study analyzes the local energy planning (LEP), a set of urban energy strategies and potential scope, for São Paulo from 2014 to 2030. A simulation model is used to quantify the impacts of implementing LEP strategies on the city's energy system based on three indicators: energy demand, percentage usage of renewable sources, and greenhouse gas (GHG) emissions. The performance of LEP strategies was analyzed for two scenarios: the first reproduces the city policies in force, and the second expands the population's access to city energy services. Considering the implementation of LEP in the first scenario, the city exhibits a $65 \%$ usage of renewable energy and a $43 \%$ reduction in $\mathrm{GHG}$ emissions in 2030. Furthermore, implementation of the same strategies in the second scenario, also for 2030 , results in a $67 \%$ usage of renewable energy with a $24 \%$ reduction in emissions compared to 2014 .
\end{abstract}

Keywords: São Paulo Megacity; LEAP simulation model, Inequality; Decentralization; Energy.

São Paulo. Vol. 24, 2021

Special Issue: Energy territories

DOI: http://dx.doi.org/10.1590/1809-4422asoc20200059r2vu2021L3DE 


\section{Introduction}

Increasing global urbanization (cities have hosted more than half of the world's population since 2007) has led to a corresponding increase in demands for energy and resources. Scientific communities have established that this increase in demand is responsible for $2 / 3$ of global primary energy consumption that contributes $60 \%-80 \%$ of total $\mathrm{CO}_{2}$ emissions (ROSALES CARREÓN; WORRELL, 2018; YAZDANIE; DENSING; WOKAUN, 2017). This trend of correspondence highlights the requirement of synergistic action between energy and urbanism (COLLAÇO, 2019).

The impact magnitude of cities is increasing together with the number of cities (cities with 10 million or more inhabitants) that are primarily located in developing countries (UN-HABITAT, 2016). Thus, reducing social inequalities in urban regions by increasing the urban population's access to energy is crucial for improving social wellbeing (Rutter \& Keirstead, 2012).

Yazdanie, Densing and Wokaun (2017) suggests that cities are a strategic place for implementing energy mitigation and adaptation initiatives, which can be formulated in an optimized and contextualized manner, considering urban energy systems (UES). However, as reported by Collaço et al. (2019a), the urban energy requirements of cities by sector and end-use, have been insufficiently investigated. Furthermore, there is a lack of knowledge regarding the detailed energy supply profile, particularly, on the local potential of energy resources provision in cities (COLLAÇO et al., 2019a).

Several scientific publications have used modeling tools to analyze UES (SAMSATLI; SAMSATLI, 2018). Peng et al. (2015) used the LEAP simulation model to study urban passenger transport in Tianjin. Yang et al. (2017) and Zhang, Feng, and Chen (2011) used LEAP to analyze the implications of low-carbon policies for cities in China (Ningbo and Beijing, respectively); Phdungsilp (2010) used the LEAP software to visualize the impact of low-carbon policies for Bangkok, Thailand. Collaço et al. (2019b, 2019a) applied the LEAP simulation model to São Paulo (LEAP_SP) to quantify the integration synergies between urban and energy planning strategies in terms of GHG emissions, fossil versus renewable resources usage, and increase in local energy generation. The present study uses the referred LEAP_SP model to analyze the potential application of LEP for reducing inequality of energy service access in São Paulo.

A simulation model of the energy system using the LEAP system is presented for the 2014-2030 period. Four scenarios were modeled for the Brazilian city of São Paulo: two each for inclusion trajectory and energy policy implementation. The inclusion trajectory scenarios are Business as Usual (BAU) and More Inclusive City (MIC), which were simulated according to two variations: the first considers the maintenance of the current situation (Historic), and the second implements a package of 17 LEP goals, resulting in four scenarios for the development of the analysis: Business as Usual-historic (BAU-H), Business as Usual-LEP (BAU-LEP), More Inclusive City-historic (MIC-H), and More Inclusive City-LEP (CMI-LEP).

Following this development, we analyzed the results in terms of renewable increase, energy savings, and reduction of GHG emissions in the city. Thus, advancing in research 
on the establishment of equal cities that provide more access to services and have lower dependency on resources, energy flows, and imported materials.

\section{Cities and Energy Planning}

Cities are encouraged to reduce $\mathrm{CO}_{2}$ emissions by implementing energy planning actions, strategies, and policies (COLLAÇO et al., 2020; COLLAÇO; BERMANN, 2017). The consumption of fossil fuels in cities is one of the leading causes of climate change (WEBB; HAWKEY; TINGEY, 2016), and there is a growing interest in reducing energy dependence in cities while promoting the transition to more sustainable energy systems (COVENANT OF MAYORS, 2014). However, little is known about UES in cities.

Many researchers have identified different factors that influence energy consumption in cities; they include structural factors, processes, patterns, and mechanisms of urbanization that substantially affect human structures and behavior. Therefore, the approach of integrating urban and energy planning can be used to develop cities with improved sustainability (JOVANOVIC et al., 2010); such an integration can lead to improved energy conservation (EC), energy efficiency (EE), and lower GHG and pollutant emissions (KEIRSTEAD; CALDERON, 2012). It also enables the development of local energy production (ADHIKARI et al., 2012).

In Brazil, the potential capacity of cities to act on EE, CE, and promote distributed generation has been overlooked as the National Energy Policy focuses on expanding supply through centralized energy planning. Due to its exclusive prerogative over the performance of the federal scope in energy planning, the National Energy Policy disregards the performance and applications of LEP.

\section{Materials and Methods}

All information collected regards the geographic scope of the São Paulo municipality. Information collected refers to the activities that occur within the city limits and is structured considering analysis of the primary energy supply and consumption of energy in the residential, public (buildings and lighting), commercial and services (C\&S), industrial, sanitation, urban mobility (UM), energy, and air transport sectors. In particular, the consumption for the energy sector considers electricity consumption for transmission and distribution, and NG consumption for cogeneration activities. The model used in this study is presented in detail by Collaço et al. (2019a).

Data and information on demand, supply, and energy transformations were collected, with 2014 as the base year. In LEAP_SP, the configuration of the base year and the macroeconomic assumptions of the two scenarios (BAU and MIC) reflect the 2014 socioeconomic situation of the population together with urban and energy policies. Information about the city's energy services was configured as a percentage of the population served for each service by analyzing urban and policy policies. Forecasts for demand data and other assumptions can be seen in more detail in Collaço et al. (2019a). 
Figure 1- Overview of the São Paulo LEAP model

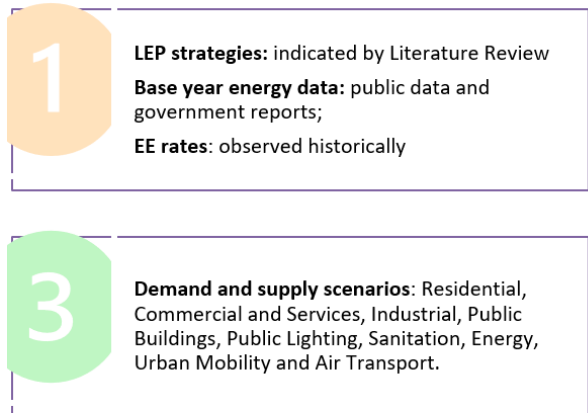

Main assumptions: scenarios and data according to official projections and with policies in force (national, state and municipal) that impact the demand and supply of energy in the city considering the base year

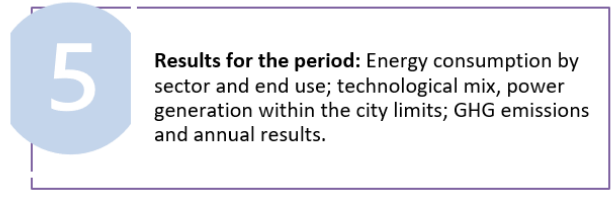

Source: Adapted from Collaço et al., 2019a.

Information on end-use energy technologies was estimated based on the property rates observed for the southeast region, according to the tenure survey (ELETROBRAS; PROCEL-INFO, 2007). Such data were verified against data from the last national census (Brazilian Institute of Geography and Statistics, 2010) and with the socioeconomic data of the city (SMDU; DEINFO, 2014). Also, data on the technical and economic potential of current and future sources of primary energy supply included in this study are solar photovoltaic systems, imports of oil products, hydraulic generating plants, biomass and biogas from pruning, urban solid waste (MSW), urban livestock, urban agriculture, and the potential for sanitation and cogeneration. Calculation of the solar photovoltaic potential was based on the current installed capacity (until March 2018) within the city, based on data from Aneel's Generation Information Bank (BIG). This was used as a basis to determine the installed capacity within the city for all energy sources of electricity generation, the solar potential of São Paulo (SECRETARIA DE ENERGIA DO SÃO PAULO STATE, 2013a), and the technical parameters reported by other sources ${ }^{1}$. More information can be seen in Collaço, et al. 2019a.

The expansion options considered for hydroelectricity were limited to retrofit/ retraining and modernization of the existing unit in the city $(\mathrm{CGH})$, as established in Bianchi (2002). This is due to a lack of space in the city for new hydroelectric plants. The potential to expand electricity generation in the city through biomass and biogas was attributed to pruning resources and maintaining green areas in the city (São Paulo City Hall, 2014; São Paulo City Hall, 2010; Rede Nossa São Paulo, 2014), biodigestion of the organic fraction of MSW, residual agricultural and livestock produce in the city, and sanitation (JACOBI; BESEN, 2011; SECRETARIA DE AGRICULTURA E ABAS-

1 - São elas: EPE, 2014; KONZEN, 2014; SIGNORINI; VIANNA e SALAMONI, 2014. 
TACIMENTO, 2009; SILVA et al., 2015).

Different types of materials and construction were not included in the model for buildings. The historical evolution of energy resource consumption (from 2007 to 2017) in the city was considered to estimate the future energy demand and end-use. The data were obtained from the historical analysis of the annual energy consumption statistics by municipality, provided by the São Paulo State Department of Energy and Mining (SECRETARIA DE ENERGIA DO SÃO PAULO STATE, 2007, 2008, 2009, 2010, 2011, 2012, 2013, 2014, 2015, 2016, 2017). There is a 14\% recorded loss grid rate for electricity in southeast São Paulo in the base year (MINISTÉRIO DE MINAS E ENERGIA, 2016). Noncommercial energy was not included in the analysis.

The model does not consider the $\mathrm{CO}_{2}$ emissions from imported products and energy. But $\mathrm{CO}_{2}$ emissions from the national grid's imported electricity was considered in this model exercise. Thus, the assumed grid emission factor was $0.11 \mathrm{tCO} / \mathrm{MWh}$, an average annual emission factor calculated between 2013 and 2017 (MCTIC, 2017). This emission factor was applied to the results of city emissions for each scenario, including the GHG emissions associated with electricity imports in the city (COLLAÇO et al., 2019a).

Limitations include sectors such as air transport and energy-containing strategies that are not directed and simulated. Similarly, strategies for all end-uses and energy technologies (i.e., cooking, vertical transport, motorcycles, trains, and subways) were not simulated. This is due to the lack of local data for these sectors and end-uses. LEAP_SP begins in 2014 and ends in 2030 and provides annual results without sub-annual temporal resolution (COLLAÇO et al., 2019a).

\section{LEAP_SP simulated scenarios}

Four scenarios were simulated and distributed in two types of inclusion or socioeconomic development trajectories (BAU and MIC) according to two perspectives of policy adoption ( $\mathrm{H}$ and LEP). The categorization allowed analyses of its impacts on energy savings, percentage of renewable sources use, and reduction of GHG emissions. The simulated scenarios are as follows:

- BAU, in which the coverage and access to city services rates (percentage of public lighting, coverage of environmental sanitation, UM index, end-use of energy, among others) were maintained as observed in 2014, until the end of the simulation exercise in 2030.

- MIC, in which the coverage rates and access to services were altered to simulate the increase in city energy services access, either by (i) universal access to services; $11 \%$ of the Sao Paulo population (amounting to more than 1 million) lives in substandard housing and lacks access to public services, according to the 2010 Census (SMDU; DEINFO, 2014); or (ii) increasing the percentage of coverage of municipal public services that are not yet fully provisioned in the city in the BAU scenario, such as the sewage collection and treatment rate. 
The two options for socioeconomic development were analyzed based on two variations: maintenance of the current situation of the current energy policy $(\mathrm{H})$, i.e., without implementing local planning strategies, and implementing a package of 17 energy policy goals presented in Table 1 . These policies consider technological substitution and $\mathrm{EE}$, substitution of fuels, and promotion of local energy generation (solar thermal and electricity).

Table 1 - Policies modeled by scenario

\begin{tabular}{|c|c|c|c|c|}
\hline Strategies & BAU-H & MIC-H & BAU-LEP & MIC-LEP \\
\hline Main assumptions & As in 2014 & $\begin{array}{c}\text { Greater than } \\
2014\end{array}$ & As in 2014 & $\begin{array}{c}\text { Greater than } \\
2014\end{array}$ \\
\hline $\begin{array}{l}\text { GHG mitigation } \\
\text { policy }\end{array}$ & Without & Without & With & With \\
\hline $\begin{array}{l}\text { Use of kerosene for } \\
\text { lighting }\end{array}$ & As in 2014 & As in 2014 & No use & No use \\
\hline More LED lighting & As in 2014 & As in 2014 & Double & Double \\
\hline More efficient cooling & As in 2014 & As in 2014 & Double & Double \\
\hline $\begin{array}{l}\text { More solar water } \\
\text { heating }\end{array}$ & As in 2014 & As in 2014 & Double & Double \\
\hline $\begin{array}{l}\text { More GN water heat- } \\
\text { ing }\end{array}$ & As in 2014 & As in 2014 & Double & Double \\
\hline $\begin{array}{l}\text { More efficient equip- } \\
\text { ment - air coolers }\end{array}$ & As in 2014 & As in 2014 & Double & Double \\
\hline $\begin{array}{l}\text { Energy Management- } \\
\text { industrial }\end{array}$ & Without & Without & With & With \\
\hline $\begin{array}{l}\text { More efficient water } \\
\text { pumps }\end{array}$ & Without & Without & With & With \\
\hline $\begin{array}{c}\text { Fuel substitution - } \\
10 \%\end{array}$ & Without & Without & With & With \\
\hline More electric cars & Without & Without & With & With \\
\hline More hybrid buses & As in 2014 & As in 2014 & Double & Double \\
\hline Fewer network losses & As in 2014 & As in 2014 & Double & Double \\
\hline $\begin{array}{l}\text { Retrofit old power } \\
\text { plants }\end{array}$ & Without & Without & With & With \\
\hline $\begin{array}{l}\text { Use of local energy } \\
\text { resources }\end{array}$ & Without & Without & With & With \\
\hline $\begin{array}{l}\text { More photovoltaic so- } \\
\text { lar generation - } 16.5 \% \\
\text { of roofs }\end{array}$ & Without & Without & With & With \\
\hline
\end{tabular}

Source: adapted from COLLAÇO et al., 2019a. 
The model sought to analyze the impacts of each social inclusion scenario (BAU and MIC) according to two perspectives for implementing policies ( $\mathrm{H}$ and LEP). Impacts where measured according to: i) energy savings through EE and EC; ii) promoting the distributed generation and increasing the use of renewable resources in the city; and iii) reducing local GHG and pollutant emissions, through composing and combining different policies that include traditional strategies within the scope of energy planning. This research assumes that understanding UES can promote public policies that focus on a more balanced urban environment, which would improve citizens' lives and promote healthier cities (SALDIVA, 2018).

\section{Results and discussion}

According to the historical data analysis on energy consumption in São Paulo², there has been a progressive increase in electricity demand in city buildings (COLLAÇO, 2019). In 2014, the UM sector consumed the most energy in the city, accounting for $58 \%$ of the final energy consumption in the city. This was followed by the residential sector, accounting for $15 \%$ of the final energy consumption. The C\&S sector consumed, representing 13\% of final consumption (COLLAÇO, et al., 2019a).

In 2014, electricity was the most demanded energy resource accounting for $36 \%$ of the city's final energy demand, followed by gasoline, accounting for $25 \%$ of final energy demand, and diesel, accounting for $16 \%$ of the final energy demand. These resources represent $77 \%$ of the energy resource needs of São Paulo. In total, $32 \%$ of the energy demand in São Paulo came from renewable resources (133 PJ) and 68\% from fossil fuels (234 PJ). The majority of fossil fuel final energy demand occurred in the UM sector (assuming that road transport and air transport are characterized by demand of $76 \%$ and $100 \%$ of fossils, respectively). In second place was the energy sector with $70 \%$ of the final energy consumption made up of fossil sources; and third, the industrial sector, with 67\% of energy consumption coming from these sources (COLLAÇO, 2019).

The sectors with the largest share of $75 \%$ renewable sources were public buildings, public lighting, and sanitation. This is due to the limited available energy data corresponding to electricity consumption for such sectors. Thus, all the electricity consumed was imported from the grid. Therefore, the values were divided by the composition of the electricity generated in Brazil in 2014; i.e., 75\% came from renewable sources, while 25\% came from fossil sources (COLLAÇO, 2019).

Considering the installed capacity of 901.5 MW in the city in 2014 (BIG-Aneel, 2019), the LEAP model calculated an electricity generation corresponding to 4 TWh. The production of electricity that occurs within São Paulo is mainly for local production in the industrial sector, hospitals, shopping malls, etc. The city matrix is based mainly on fossil energy resources, $93 \%$ of electricity production in the city, according to the model's

2. The reports were consulted: National Energy Balance 2015, from the Ministry of Mines and Energy (MME), and the statistical annuals of energy sources by municipality in the state of São Paulo, from the Energy Secretariat of the State of São Paulo (2017, 2016, 2013a, 2012, 2010a, 2010b, 2008, 2007). 
results, originating from fossil sources, mainly diesel (33\% of generation), NG (30\%), and fuel oil (30\%) (COLLAÇO, 2019).

According to the model's results, considering the UES described and GHG emissions, the city emitted 1.8 million tCO2e/ inhabitant and 20.7 million tCO2e in 2014. UM contributed the most to these emissions accounting for $74 \%$ of the total emissions, followed by households accounting for $9 \%$ of emissions, and industries accounting for $7 \%$. Gasoline, accounting for $40 \%$ of emissions, is the energy resource responsible for most GHG emissions, while diesel and NG accounted for $27 \%$ and $12 \%$, respectively (COLLAÇO, 2019).

\section{Results for the 2030 scenarios}

Graphic 1 shows the performance of each scenario (BAU-H, MIC-H, BAU-LEP, and MIC-LEP) in terms of the final energy consumption in the city. The scenario that represents the current modus of city development is BAU-H. In this scenario, there is an increase in the final demand for energy ( $71 \%$ growth) compared to the base year. In turn, the scenario that improves access to city services and does not implement LEP strategies (MIC-H) presents a further increase in the demand for energy (130\%).

Graphic 1 - Evolution of final energy consumption, by sector and scenario (2014-2030)

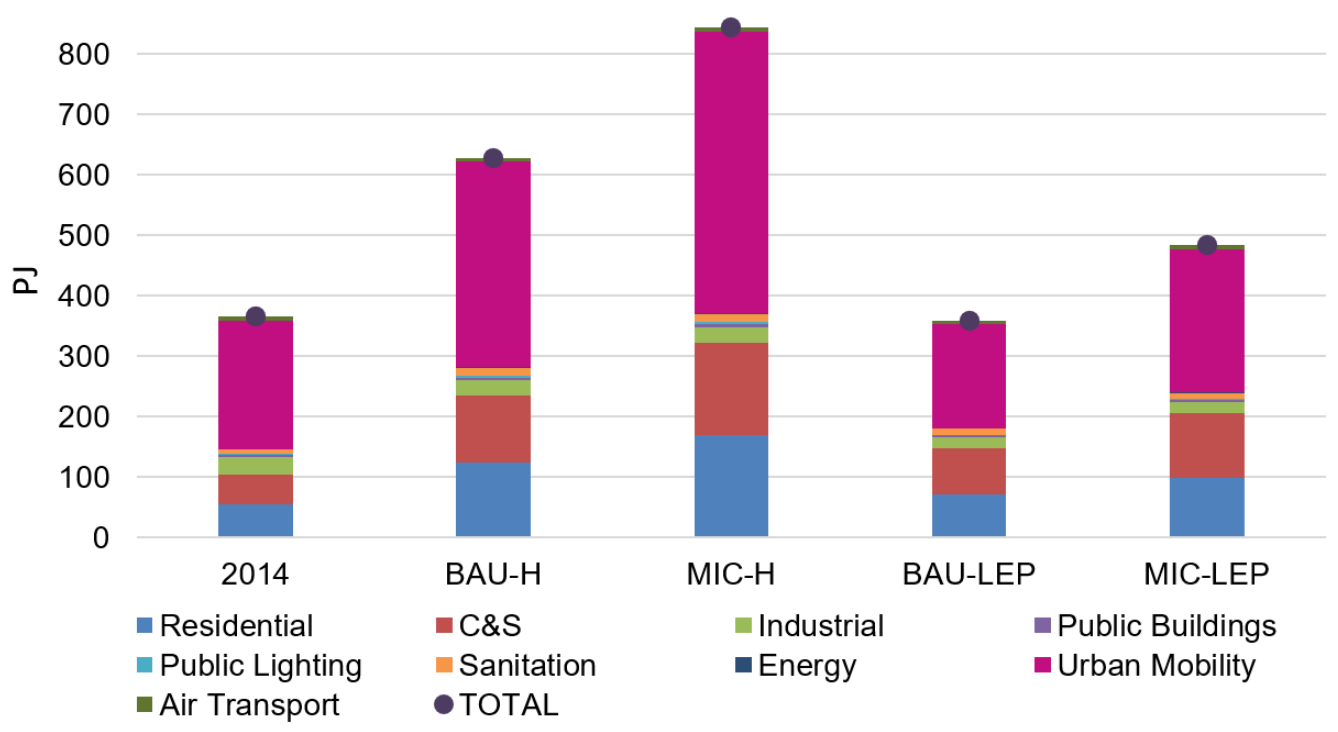


Scenarios that implemented the energy policy package effectively reduced energy demand, with the BAU-LEP scenario saving the most energy (269 PJ). Specifically, there was a $23 \%$ reduction in demand when compared to the BAU-H scenario and $43 \%$ when compared to the MIC-H scenario. As expected, the MIC scenarios led to higher energy consumption, as they considered greater coverage of city services and expanded access to them. However, it is important to note that the MIC-LEP scenario performs better than the city's current development trajectory (scenarios with variables $\mathrm{H}$ ), reducing demand by 144PJ (compared to BAU-H).

Regarding the performance of each scenario in local electricity production between 2014 and 2030, it is assumed that electricity generation in the base year was 4TWh, meeting only $9 \%$ of the city's electricity needs. With the city importing $99 \%$ of its need for energy resources, the remaining $91 \%$ of the demand is supplied by the national network. In addition, a marked reduction in the city's installed capacity of approximately $89 \%$ (BAU-H) is expected, owing to the improved lifespan of urban electricity generation plants. In scenarios that implement strategies for distributed generation and retrofitting of the plants in the city (BAU-LEP and MIC-LEP), 13 TWh of electricity is generated locally. A summary of the results of this model is presented in Table 2.

Table 2 - Summary of the performance of the scenarios by indicators

\begin{tabular}{|c|c|c|c|c|c|}
\hline$\underline{\text { Indicators / Scenarios }}$ & $\underline{2014}$ & $\frac{\underline{\text { BAU-H }}}{(2030)}$ & $\frac{\underline{\text { MIC-H }}}{(2030)}$ & $\frac{\underline{\text { BAU-LEP }}}{(2030)}$ & $\frac{\text { MIC-LEP }}{(2030)}$ \\
\hline Final demand (PJ) & 367 & 628 & 844 & 359 & 484 \\
\hline $\begin{array}{c}\text { Emissions (million } \\
\text { tCO2e / inhabitant) }\end{array}$ & 1.80 & 2.58 & 3.44 & 1.03 & 1.37 \\
\hline $\begin{array}{c}\text { \% Renewables in the } \\
\text { city's energy balance }\end{array}$ & $32 \%$ & $40 \%$ & $41 \%$ & $65 \%$ & $67 \%$ \\
\hline
\end{tabular}

The predominance of fossil energy in 2030 is maintained in scenarios based on historical rates (BAU-H and MIC-H) (COLLAÇO, et al., 2019a). In the 2030 LEP scenarios, fossil fuel consumption is reduced by about $50 \%$ compared to 2014 figures, owing to the increase in renewable resources in electricity generation and fuel substitution (see Figure 2). The most significant change occurs with the implementation of a strategy that restricts the use of fossil fuels in the UM sector.

This strategy sought to implement a goal that existed in the city's climate policy and proposed the replacement of $10 \%$ of fossil fuels with renewables in the transport sector; this was also extended to private transport in the city. Therefore, in the BAU-LEP scenario, renewables have a $65 \%$ share in the total energy demand and $76 \%$ in electricity by 2030 . In the MIC-LEP scenarios, the city would achieve a $67 \%$ share of renewables in the total demand for energy and $76 \%$ in demand for electricity at the end of the simulation period.

The current policy (BAU-H) does not reduce GHG emissions until 2030, and instead, increases them by about $44 \%$ compared to 2014 values $(1.8$ million tCO2e/ 
inhabitant in 2014 and 2.6 million tCO2e/inhabitant in 3030). This scenario worsens if there is an increase in access to services in the city unaccompanied by the implementation of mitigation policies (a result reflected by the MIC-H scenario), which would result in a multiplication of double the emissions compared to 2014 (i.e., in 2030, CMI -H would result in 3.4 million tCO2e/inhabitant).

Conversely, when implementing policies that decrease demand and increase the use of renewables (scenarios that implement LEP), a positive outcome is reflected in total and per capita emissions. For example, the BAU-LEP scenario reduces city emissions by about 43\% (from 1.8 million tCO2e/inhabitant in 2014, to 1.1 million tCO2e/inhabitant in 2030). However, this scenario does not reduce inequality in access to city services.

Contrarily, in the MIC-LEP scenario, access to city services is increased, while a $24 \%$ reduction in emissions is achieved compared to the base year (in 2030, MIC-LEP totaled 1.4 million tCO2e/inhabitant). Therefore, it can be concluded that even in the MIC-LEP scenario, which provides access to city services but implements LEP strategies, there is a decrease in $\mathrm{CO}_{2}$ emissions when compared to the scenario that simulates the maintenance of the current situation in the city (BAU-H); 24\% in 2014 and 43\% in 2030.

The efficient outcome in the LEP scenarios is a consequence of the reduction of imported electricity from the grid due to the increasing local generation of electricity with renewables, and because of the replacement of fossil fuels by renewables on public transportation.

Notably, public material made available by EPE for the first half of 2020 , including analysis of the impact of Covid-19, exhibited a significant drop in national GDP, as well as in energy consumption by $4.5 \%$ in comparison with the same period of the year 2019 . This was accompanied by a 5\% drop in power generation and a $19 \%$ reduction in GHG emissions from the electricity sector and $11 \%$ in the transport sector (EPE, 2020). Thus, it is expected that such a reduction in energy demand and resulting emissions has also occurred within São Paulo.

According to the Intergovernmental Panel on Climate Change (IPCC), the pandemic adds to various systemic and ecosystem crises when it is no longer possible to postpone decisions that will rapidly and crucially affect the planet's habitability. This is because science conditions the possibility of stabilizing the average global warming within, or not much beyond, the limits desired by the Paris Agreement (2015) to the primordial fact that $\mathrm{CO}_{2}$ emissions would reach the maximum limit of 2020 to reach its peak, and then start to decline strongly (MARQUES, 2020).

The IPCC outlined 196 scenarios through which it would be possible to limit the average global warming to about $0.5^{\circ} \mathrm{C}$ above the current average warming during the pre-industrial period $\left(1.2^{\circ} \mathrm{C}\right.$ in 2019$)$, but none of the scenarios admit that the peak of $\mathrm{GHG}$ is postponed beyond 2020 (HOOPER, 2020). To further complicate the global climate emergency, the 2019 assessment by the World Resource Institute (WRI) demonstrated that, in most cases, mitigating countries' actions was insufficient or of no progress.

According to the same report, none of the goals were achieved; in December 2019, the COP25 in Madrid ended, largely due to the governments of the USA, Japan, Aus- 
tralia, and Brazil (IRFAN, 2019). This affected hopes of reducing global GHG emissions (MARQUES, 2020). LEP scenarios were designed to assist cities with actions within their scope and in favor of climate action and reduction of social inequality.

Finally, it is worth clarifying that not even the pandemic was able to reduce $\mathrm{CO}_{2}$ concentration in the atmosphere. According to the UN Meteorological Agency, the 2019 concentrations of 410 parts per million, as well as the accumulated emissions from previous years, had an upward trend continuing in 2020 (OMM-UN, 2020).

\section{Conclusion}

Considering only the energy indicators used in this study, such as increasing renewable energy, final energy demand, and GHG emissions, the model results show that the BAU scenario presented the best energy performance. However, the MIC scenario represents a significant increase in the quality of life of many city dwellers and can be a possible scenario for a more sustainable and less unequal urban energy system.

Currently, São Paulo largely uses fossil energy sources, consuming about $68 \%$ in 2014 and 60\% in 2030 (BAU-H). However, since EE strategies have gained traction from both the demand and supply side (implementation of LEP) in 2030 in the BAU-LEP scenario, this rate could be reduced to $35 \%$ with the increased participation of renewable sources and a possible reduction of up to 43\% in GHG emissions based on the 2014 emission levels. In turn, when considering the best access to energy services for city dwellers (MIC-LEP scenario), a maximum of $67 \%$ renewable energy share could be achieved in 2030 and an emission reduction of $24 \%$ as compared to 2014 emissions.

Thus, reducing social inequalities in São Paulo is possible when LEP measures are implemented. Even though the MIC scenarios show a small increase in demand and GHG emissions when compared to the BAU scenario (33\% and 35\% more emissions and energy demand, respectively), it is important to consider that the São Paulo emissions index was 1.8 million tCO2e/inhabitant in 2014 (the model results, validated by the recent SEEG initiative of the Climate Observatory, launched in 2021, estimated 2014 emissions at 1.76 million tCO2e/inhabitant). Therefore, it is lower than that of developed countries, which should reduce their emissions from 5.0 million $\mathrm{tCO}$ e per capita to 2.9 million $\mathrm{tCO}$ e by 2020 (C40 CITIES; ARUP, 2015).

In the predicted scenarios, the São Paulo index will reach 1.03 million tCO2e/ inhabitant in the BAU-LEP scenario and 1.4 million tCO2e/inhabitant in the MIC-LEP scenario by 2030, remaining below the target of developed countries even in the scenario of greater inclusion and demand for energy. This can also be attributed to the annualized EE rate adopted in the model for the two scenarios being less than $1 \%$ per year, which is highly conservative and restrictive.

A sustainable and more inclusive transition is feasible. However, further research is needed to ensure that this transition is economically, institutionally, politically, and socially viable from a governance standpoint.

Finally, the results of this research highlight that acting based on traditional EE 
policies, oriented mainly toward technological substitution, are effective, especially when seeking to reduce inequality, but are insufficient in achieving a significant reduction in consumption and dependence on exogenous energy resources in cities. In this sense, it is important to analyze substantial changes in the orientation of current sectoral and energyintensive policies. Even the search for the inclusion of renewable energies assumes an incessant need to increase the demand and consumption of resources. Further research is required to address the impacts of a paradigm shift on energy use and consumption and the establishment of equal societies.

\section{Acknowledgements}

We are grateful for the support of the CAPES agency through the Programa de Doutoramento Sanduiche (PDSE), from the RCGI-Research Center for Gas Innovation, located at USP and financed by FAPESP (process no 2014 / 50279-4) and Shell Brasil. And again to FAPESP through process No. 2015 / 03804-9.

\section{References}

ADHIKARI, R. S.; ASTE, N.; MANFREN, M. Optimization concepts in district energy design and management - A case study. Energy Procedia, v. 14, p. 1386-1391, 2012. DOI: 10.1016/j. egypro.2011.12.1106.

ASSOCIAÇÃO NACIONAL DE TRANSPORTES PÚBLICOS - ANTP. Sistema de Informações da Mobilidade Urbana Relatório Geral 2014. Brasília: 2016. Disponível em: <http:// www.antp.org.br/5dotSystem/download/dcmDocument/2013/04/11/050FC84C-74EA-4A33A919-6D2E380FĀ2C1.pdf>.

BIANCHI, Inácio; SOUZA, Teófilo Miguel. Recapacitação e repotencialização de pequenas centrais hidrelétricas desativadas ou em operação no estado de São Paulo, 2002.

BRASIL; MINISTÉRIO DE MINAS E ENERGIA. Plano Nacional de Energia 2030 (PNE, 2030). Brasilia: MME/EPE, 2007.

BRASIL; MINISTÉRIO DE MINAS E ENERGIA. Plano Nacional de Eficiência Energética. Brasília.

BRISTOW, D. N.; KENNEDY, C. A. Maximizing the use of energy in cities using an open systems network approach. Ecological Modelling, v. 250, p. 155-164, 2013.

BROCKWAY, P. E. et al. Energy rebound as a potential threat to a low-carbon future: Findings from a new exergy-based national-level rebound approach. Energies, v. 10, n. 1, 2017.

BROWNSWORD, R. A. et al. Sustainable cities - Modelling urban energy supply and demand. Applied Energy, v. 82, n. 2, p. 167-180, 2005.

C40 CITIES; ARUP. Deadline 2020 - how cities will get the job done. 2015. 
CAJOT, S.; PETER, M.; BAHU, J.; KOCH, A.; MARÉCHAL, F. Energy planning in the urban context : challenges and perspectives. Energy Procedia, v. 78, n. 0, p. 3366-3371, 2015. DOI: 10.1016/j.egypro.2015.11.752.

COLLAÇO, F. M. DE A. SINERGIAS ENTRE O PLANEJAMENTO ENERGÉTICO E O PLANEJAMENTO URBANO: ESTUDO DE CASO DO SISTEMA DE ENERGIA URBANO DA MEGACIDADE DE SÃO PAULO. [2019. 233f. Doutorado (Doutorado em Ciência da Energia) - Instituto de Energia e Ambiente, Universidade de São Paulo, 2019.

COLlAÇO, Flávia Mendes de Almeida; BERMANN, Célio. Perspectivas da gestão de energia em âmbito municipal no Brasil. Estudos Avancados, v. 31, n. 89, p. 213-235, 2017. DOI: 10.1590/s0103-40142017.31890018.

COLLAÇO, Flávia Mendes de Almeida; DIAS, Luís Pereira; SIMOES, Sofia G.; PUKŠEC, Tomislav; SEIXAS, Júlia; BERMANN, Célio. What if São Paulo (Brazil) would like to become a renewable and endogenous energy -based megacity? Renewable Energy, v. 138, p. 416-433, 2019. a. DOI: $10.1016 /$ j.renene.2019.01.073.

COLLAÇO, Flávia Mendes de Almeida; SCHIRMER SOARES, Raiana; BENITES-LAZARO, Lira Luz; BEREJUK, Guilherme; MOTT PAVANELLI, João; LAMPIS, Andrea; BERMANN, Célio. Identificação do Sistema Energético da Macrometrópole Paulista: primeiro passo para atuação local em Mudanças Climáticas. Ambiente $\mathbb{\&}$ Sociedade, v. 23, n. Na imprenta, 2020.

COLLAÇO, Flávia Mendes de Almeida; SIMOES, Sofia G.; DIAS, Luís Pereira; DUIC, Neven; SEIXAS, Júlia; BERMANN, Célio. The dawn of urban energy planning - Synergies between energy and urban planning for São Paulo (Brazil) megacity. Journal of Cleaner Production, v. 215, p. 458-479, 2019. b. DOI: 10.1016/j.jclepro.2019.01.013.

COMITÊ INTERSETORIAL PARA A POLÍTICA MUNICIPAL DE RESÍDUOS SÓLIDOS. Plano de Gestão Integrada de Resíduos Sólidos da Cidade de São Paulo. São Paulo - SP Brasil.

COVENANT OF MAYORS. Reducing Energy Dependence in European Cities. p. 1-17, 2014.

ELETROBRAS; PROCEL-INFO. PESQUISA DE POSSE DE EQUIPAMENTOS E HABITOS DE USO - ANO BASE 2005 (Região Sudeste). Rio de Janeiro : 2004.

EMPRESA DE PESQUISA ENERGÉTICA - EPE. Plano Nacional de Energia 2050- Estudo sobre a Demanda. Rio de Janeiro - RJ - Brasil: 2018. Disponível em: < http://informesanuales. xm.com.co/2013/SitePages/operacion/3-1-Demanda-de-energia-nacional.aspx $>$.

EMPRESA DE PESQUISA ENERGÉTICA - EPE. Plano Decenal de Expansão de Energia 2026 - Capítulo Introdução. Rio de Janeiro - RJ - Brasil: 2016.

EMPRESA DE PESQUISA ENERGÉTICA - EPE. Balanço COVID-19 - Imapctos nos mercados de energia no Brasil, 1 semestre de 2020. Rio de Janeiro - RJ - Brasil: 2020. Disponível : < https://www.epe.gov.br/sites-pt/publicacoes-dados-abertos/publicacoes/PublicacoesArquivos/ publicacao-500/Balanco_Covid-19\%20-rev.pdf> 
FARZANEH, Hooman; SUWA, Aki; DOLLA, Christopher N. H.; OLIVEIRA, Jose Antonio Puppim De. Developing a Tool to Analyze Climate Co-benefits of the Urban Energy System. Procedia Environmental Sciences, v. 20, p. 97-105, 2014. DOI: 10.1016/j.proenv.2014.03.014.

FARZANEH, H.; DOLL, C. N. H.; PUPPIM DE OLIVEIRA, J. A. An integrated supply-demand model for the optimization of energy flow in the urban system. Journal of Cleaner Production, v. 114, p. 269-285, 2016.

GARGIULO, M. et al. An Integrated Planning Framework for the Development of Sustainable and Resilient Cities - The Case of the InSMART Project. Procedia Engineering, v. 198, n. September 2016, p. 444-453, 2017.

HEAPS, Charlie. LEAP Data Requirements for Energy Planning and Mitigation Assessment. n. February, p. 1-4, 2006.

IEA. World Energy Outlook 2016. International Energy Agency: Paris, France, p. 28, 2016.

INSTITUTO BRASILEIRO DE GEOGRAFIA E ESTATÍSTICA- IBGE. Atlas do Censo Demográfico. 2010.

INTERNATIONAL ENERGY AGENCY - IEA. Energy Technology Perspectives 2016. Paris: 2015.

JACOBI, Pedro Roberto; BESEN, Gina Rizpah. Gestão de resíduos sólidos em São Paulo: desafios da sustentabilidade. Estudos Avançados, v. 25, n. 71, p. 135-158, 2011. DOI: 10.1590/S010340142011000100010.

JIN, X. et al. Optimal day-ahead scheduling of integrated urban energy systems. Applied Energy, v. 180, p. 1-13, 2016.

JOVANOVIC, Marina; AFGAN, Naim; BAKIC, Vukman. An analytical method for the measurement of energy system sustainability in urban areas. Energy, v. 35, n. 9, p. 3909-3920, 2010. DOI: $10.1016 / j$.energy.2010.06.010.

KEIRSTEAD, James; CALDERON, Carlos. Capturing spatial effects, technology interactions, and uncertainty in urban energy and carbon models: Retrofitting newcastle as a case-study. Energy Policy, v. 46, p. 253-267, 2012. DOI: 10.1016/j.enpol.2012.03.058.

LEDUC, W. R. W. A.; VAN KANN, F. M. G. Spatial planning based on urban energy harvesting toward productive urban regions. Journal of Cleaner Production, v. 39, p. 180-190, 2013.

LIU, D. et al. Study on integrated simulation model of Economic, Energy and Environment Safety system under the low-carbon policy in Beijing. Procedia Environmental Sciences, v. 5, p. 120-130, 2011.

MCTIC. Fatores de Emissão de $\mathrm{CO} 2$ para utilizações que necessitam do fator médio de emissão do Sistema Interligado Nacional do Brasil- outubro 2017. Brasília. 2016. 
MINISTÉRIO DE MINAS E ENERGIA - MME. Plano Nacional de Energia 2030 (PNE, 2030). Brasilia: MME/EPE, 2007.

MINISTÉRIO DE MINAS E ENERGIA - MME. Plano Nacional de Eficiência Energética. Brasília: MME, 2011.

MINISTÉRIO DE MINAS E ENERGIA - MME. Matrizes Elétricas Estaduais. 2016. Disponível em: <http://www.mme.gov.br/documents/10584/3580498/04+-+Matrizes+Elé tricas + Estaduais $+2016+-+$ ano + ref. $+2015+\% 28$ PDF\%29/ddfaad8c-a436-4aa8-b619f95dd2cf689c?version $=1.1>$.

MINISTÉRIO DE MINAS E ENERGIA - MME. Balanço Energético Nacional, 2018. Relatório Síntese (ano base 2017). Brasilia: 2017. Disponível em: < http://www.epe.gov.br/sites-pt/ publicacoes-dados-abertos/publicacoes/PublicacoesArquivos/publicacao-303/topico-397/Relatório Síntese 2018-ab 2017vff.pdf\#search=co2 >.

PREFEITURA DO MUNICÍPIO DE SÃO PAULO- PMSP. Plano Municipal de Saneamento Básico de São Paulo. São Paulo - SP - Brasil: 2010.

PREFEITURA DO MUNICÍPIO DE SÃO PAULO- PMSP. Plano Diretor Estratégico do município de São Paulo 2014. p. 76.

PREFEITURA DO MUNICÍPIO DE SÃO PAULO- PMSP. Plano de Mobilidade de São Paulo, 2015. São Paulo: 2014.

RAVALDE, T.; KEIRSTEAD, J. Comparing performance metrics for multi-resource systems: the case of urban metabolism. Journal of Cleaner Production, v. 163, p. S241-S253, 2017.

REDE NOSSA SÃO PAULO. PLANO DE GESTÃO INTEGRADA DE RESÍDUOS SÓ. LIDOS DA CIDADE DE SÃO PAULO: Balanço dos cinco anos da Política Municipal de Clima de São Paulo. 2014.

ROJAS, S. P. Análise Exergética, Termoeconômica E Ambiental De Um Sistema De Geração De Energia . Estudo De Caso : Usina Termoelétrica Ute - Rio Madeira. p. 176, 2007.

ROSALES CARREÓN, Jesús; WORRELL, Ernst. Urban energy systems within the transition to sustainable development. A research agenda for urban metabolism. Resources, Conservation and Recycling, v. 132, n. August 2017, p. 258-266, 2018. DOI: 10.1016/j.resconrec.2017.08.004.

RUTTER, Paul; KEIRSTEAD, James. A brief history and the possible future of urban energy systems. Energy Policy, v. 50, p. 72-80, 2012. DOI: http://dx.doi.org/10.1016/j.enpol.2012.03.072.

SABESP. Relatório de Sustentabilidade 2015. 2014.

SALDIVA, P. Vida urbana e saúde. São Paulo - SP - Brasil.: 2018.

SAMSATLI, S.; SAMSATLI, N. J. A general mixed integer linear programming model for the design and operation of integrated urban energy systems. Journal of Cleaner Production, v. 191, 
p. 458-479, 2018.

SEADE. SP Demográfico, resenha de estatísticas Vitais do estado de São Paulo: a população regional paulisra em perspectiva histórica (projeções demográficas até 2050). São Paulo - SP - Brasil.: 2017.

SEADE, F. Website SEADE. Disponível em: < http://www.seade.gov.br/lista-produtos/>. Acesso em: 24 jan. 2018 b.

SECRETARIA DE AGRICULTURA E ABASTACIMENTO. Levantamento Censitário das unidades de Produção agropecuária do estado de São Paulo. São Paulo: 2009.

SECRETARIA DE ENERGIA DO ESTADO DE SP. Anuário Estatístico de Energéticos por Município no Estado de São Paulo. São Paulo - SP - Brasil.: 2007 até 2018.

SECRETARIA DE ENERGIA DO ESTADO DE SP. Energia Solar Paulista: levantamento do potencial. São Paulo - SP - Brasil.:2011.

SILVA, Thaísa Carolina Ferreira; RIETOW, Julio Cezar; COELHO, Suani Teixeira; POSSETTI, Gustavo Rafael Collere. Utilização do Biogás proveniente do tratamento do esgoto doméstico para geração de eletricidadeSão Paulo.10 ${ }^{\circ}$ Congresso sobre Geração Distribuída e Energia no Meio Rural., 2015.

SMDU; DEINFO. Infocidade webpage. 2014.

UN-HABITAT. World Cities Report 2016 - Urbanization and Development: Emerging Futures. 2015.

MARQUES, Luis. A pandemia incide no ano mais importante da história da humanidade. Serão as próximas zoonoses gestadas no Brasil?. In UNICAMP website, 2020. Disponível em: < https:/www.unicamp.br/unicamp/noticias/2020/05/05/pandemia-incide-no-ano-mais-importante-da-historia-da-humanidade-serao-proximas?fbclid=IwAROBBOF9vdiS2qUjEOJznkMLRD2 TUHTe3LnVeweAWYha7SLMKkiV7nzcYEQ>

WEBB, Janette; HAWKEY, David; TINGEY, Margaret. Governing cities for sustainable energy: The UK case. Cities, v. 54, p. 28-35, 2016. DOI: 10.1016/j.cities.2015.10.014.

YANG, D. et al. Sectoral energy-carbon nexus and low-carbon policy alternatives: A case study of Ningbo, China. Journal of Cleaner Production, v. 156, p. 480-490, 2017.

YAZDANIE, Mashael; DENSING, Martin; WOKAUN, Alexander. Cost optimal urban energy systems planning in the context of national energy policies: a case study for the city of Basel. Energy Policy (accepted), v. 110, n. June, p. 176-190, 2017. DOI: 10.1016/j.enpol.2017.08.009.

ZHANG, L.; FENG, Y.; CHEN, B. Alternative scenarios for the development of a low-carbon city: A case study of Beijing, China. Energies, v. 4, n. 12, p. 2295-2310, 2011. 
Flávia Mendes de Almeida Collaço

凹flavia.collaco@usp.br

ORCiD: https://orcid.org/0000-0003-4277-9043
Submitted on: 02/05/2019

Accepted on: 03/03/2021 2021;24e:00592

\section{Célio Bermann}

凹cbermann@iee.usp.br

ORCiD: https://orcid.org/0000-0002-1759-7523

How to cite: COLLAÇO, Flávia Mendes de Almeida; BERMANN, Célio. Local Energy Planning Potentialities in Reducing São Paulo's inequalities. Ambiente \& Sociedade. São Paulo, v. 24, p. 1-17, 2021. 


\title{
Potencialidades do Planejamento Energético Local na redução da desigualdade na cidade de São Paulo
}

\author{
Flávia Mendes de Almeida Collaço \\ Célio Bermann
}

São Paulo. Vol. 24, 2021

Dossiê Especial:

Territórios da energia
Resumo: Este artigo analisa o potencial do Planejamento Energético Local (PEL), conjunto de estratégias de energia no âmbito urbano, na megacidade de São Paulo (período 2014 - 2030), através de modelo de simulação para quantificar os impactos da implementação destas estratégias no sistema energético da cidade segundo três indicadores: demanda de energia, \% de uso de fontes renováveis e emissões de gases de efeito estufa (GEE). O desempenho das estratégias de PEL foi analisado segundo dois cenários: o primeiro reproduz as políticas vigentes na cidade e o segundo amplia o acesso da população aos serviços de energia. Considerando a implementação de PEL no primeiro cenário, a cidade alcançará, em 2030, 65\% de energia renovável e redução de 43\% das emissões de GEEs. Se as mesmas estratégias forem implementadas no segundo cenário, $67 \%$ da participação de energia renovável será alcançada com uma redução de $24 \%$ nas emissões quando comparadas a 2014.

Palavras-chave: Megacidade; Modelo de simulação LEAP, Desigualdade; Descentralização; Energia

Como citar: COLLAÇO, F., M. A.; BERMANN, C. Potencialidades do Planejamento Energético Local na redução da desigualdade na cidade de São Paulo. Ambiente \& Sociedade. São Paulo, v. 24, p. 1-17, 2021. 


\title{
Potencialidades de la planificación energética local para reducir la desigualdad en la ciudad de São Paulo
}

\author{
Flávia Mendes de Almeida Collaço \\ Célio Bermann
}

São Paulo. Vol. 24, 2021

Dossier especial:

Territórios de Energía
Resumen: Este artículo analiza el potencial del Planeamiento Energético Local (PEL), en las megalópolis de São Paulo (período 2014 - 2030), a través de un modelo de simulación para cuantificar los impactos de la implementación de PEL en el sistema energético de São Paulo de acuerdo con tres indicadores: demanda de energía, \% de uso de fuentes renovables y emisiones de gases de efecto invernadero (GEI). Se analizó el desempeño de las estrategias del PEL según dos escenarios: el primero reproduce las políticas vigentes y el segundo aumenta el acceso de la población a los servicios energéticos. Considerando la implementación del PEL en el primer escenario, la ciudad alcanzará en 2030, 65\% de energía renovable y $43 \%$ de reducción de GEI. Si se aplican las mismas estrategias en el segundo escenario, se logrará $67 \%$ renovable con una reducción del 24\% de las emisiones en comparación con 2014.

Palabras-clave: Megaciudad; Modelo de simulación LEAP, Desigualdad; Descentralización; Energía.

Como citar: COLLAÇO, Flávia Mendes de Almeida; BERMANN, Célio. Potencialidades de la planificación energética local para reducir la desigualdade em la ciudad de São Paulo. Ambiente $\&$ Sociedade. São Paulo, v. 24, p. 1-17, 2021.

DOI: http://dx.doi.org/10.1590/1809-4422asoc20200059r2vu2021L3DE 